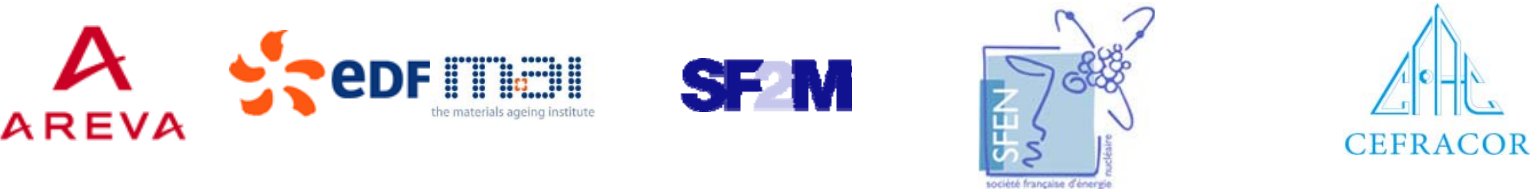

\section{MIN口S}

Centre of Excellence for Nuclear Materials

\section{Workshop}

Materials Innovation for Nuclear Optimized Systems
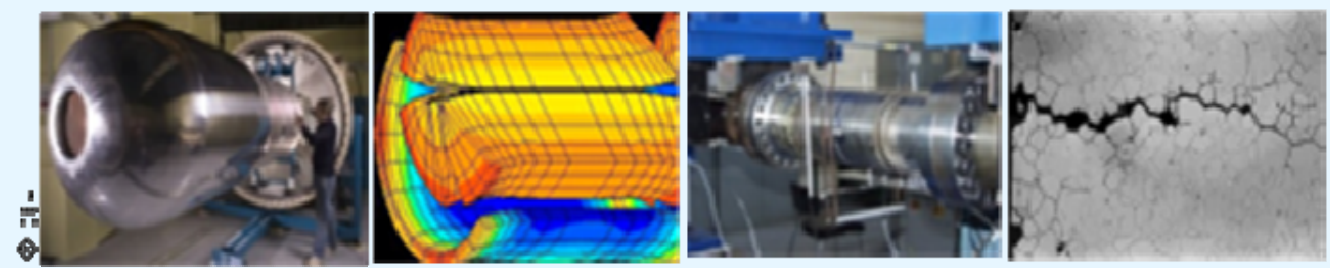

December 5-7, 2012, CEA - INSTN Saclay, France

\section{Jean HENRY et al. \\ CEA (France)}

Irradiation Resistance in a Fusion Environment: a Challenge for Structural Materials

Workshop organized by:

Christophe GALLÉ, CEA/MINOS, Saclay - christophe.galle@cea.fr Constantin MEIS, CEA/INSTN, Saclay - constantin.meis@cea.fr 
MINDS

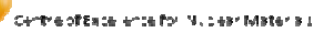

\title{
Irradiation Resistance in a Fusion Environment: a Challenge for Structural Materials
}

\author{
Jean HENRY ${ }^{1}$, Jean-Louis BOUTARD ${ }^{2}$ \\ ${ }^{1}$ CEA/DEN-DMN, Service de Recherche Métallurgiques Appliquées, SRMA (Saclay, France) \\ ${ }^{2}$ CEA, Cabinet du Haut-Commissaire (Saclay, France)
}

The safe and reliable operation of future fusion power plants will require structural materials able to withstand highly demanding operating conditions. Indeed the materials of the First Wall, Tritium Breeding Blankets or Divertor, will be subjected to intense fluxes of high energy neutrons, up to high total doses and in a wide range of in-service temperatures. In this presentation, we will discuss the irradiation behavior of candidate steels for fusion application.

In the absence of an irradiation facility with a prototypical neutron flux, irradiation effects in these materials, such as the $9 \mathrm{Cr}$ tempered martensitic steel Eurofer, were up to now assessed based in particular on experiments using fission reactors. This approach has some relevance since both experimental data and Molecular Dynamics simulations indicate that the primary displacement damage in iron is very similar after irradiation by fission or $14 \mathrm{MeV}$ neutrons. Furthermore damage rates in fusion devices will be very close to values typical of fast reactors such as BOR60.

Like other $9 \mathrm{Cr}$ martensitic steels, Eurofer steel exhibits negligible swelling and very moderate hardening and embrittlement at irradiation temperatures above approximately $380-400^{\circ} \mathrm{C}$. However results of irradiation experiments performed at $325^{\circ} \mathrm{C}$ up to about $80 \mathrm{dpa}$ in BOR60 [1] showed an important increase of the yield stress in irradiated Eurofer and a significant degradation of the impact properties (large shift of the Ductile-to-Brittle Transition Temperature and decrease of the upper shelf energy). TEM and SANS investigations revealed that these modifications of the mechanical properties are due to the irradiation-induced formation of a high density of small dislocation loops and to alpha/alpha' unmixing.

In fusion irradiation conditions, significant amounts of helium and hydrogen will be produced in the materials in addition to displacement damage. Implantation experiments using a cyclotron have revealed that helium can induce a drastic embrittlement of $9 \mathrm{Cr}$ martensitic steels, with the occurrence of intergranular fracture [2,3]. This fracture behavior is consistent with the results of electronic structure calculations which indicate that helium severely decreases grain boundary cohesion in iron. Likewise, measurements of tensile and impact properties after irradiation of $9 \mathrm{Cr}$ martensitic steels in a spallation environment show a degree of embrittlement significantly greater than that expected after irradiation in fission conditions, which is attributed in particular to the high helium content in the irradiated specimens [3]. Furthermore, results of dual $(\mathrm{Fe}+\mathrm{He})$ and triple $(\mathrm{Fe}+\mathrm{He}+\mathrm{H})$ ion beam irradiations indicate that the high swelling resistance of Ferritic/Martensitic steels might not be maintained in a fusion irradiation environment.

By contrast, Oxide Dispersion Strengthened (ODS) FM steels are promising materials for fusion application. In addition to lower irradiation-induced hardening at low temperature than FM steels [1], ODS displayed a better mechanical behavior after irradiation in spallation conditions [4]. Figure 1 shows an example of tensile curves measured on MA957 ODS irradiated in the SINQ spallation target. Irradiated MA957 retained significant ductility whereas FM steels subjected to identical irradiation conditions exhibited a brittle intergranular fracture mode. The high density of nanoclusters in ODS FM steels are believed to act as effective sinks for point defects as well as trapping sites for helium and hydrogen, which is confirmed by microstructural observations [5]. 


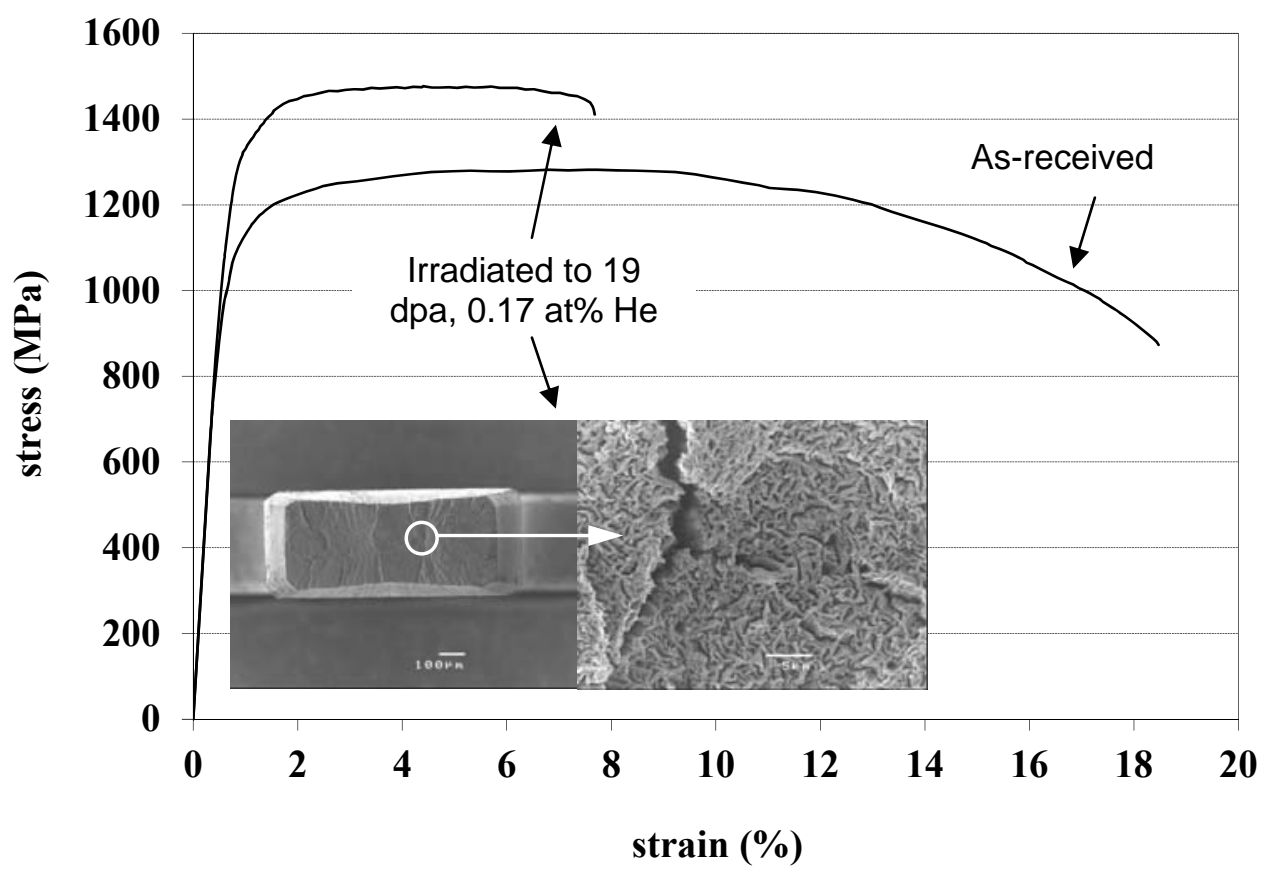

Fig. 1: Engineering tensile curve measured at room temperature and SEM micrographs showing the ductile fracture surface of MA957 ODS after irradiation at $360^{\circ} \mathrm{C}$ to $19 \mathrm{dpa}$ in the SINQ spallation target. The accumulated He content in the irradiated specimen is about 0.17 at\%. These data demonstrate the good mechanical behavior of MA957 following irradiation in an environment with high He/dpa ratio [4].

Finally it must be emphasized that the above mentioned data were not obtained in a fusion representative environment. Hence modeling of irradiation effects, which has made great progress in recent years as demonstrated by other presentations in this workshop, will be a necessary tool to extrapolate the experimental results to the real case and to optimize the experimental program to be conducted in a future intense $14 \mathrm{MeV}$ neutrons source such as IFMIF.

\section{References}

[1] J. Henry, X. Averty, A. Alamo. J. Nucl. Mater. 417 (2011) 99.

[2] R. Schäublin, J. Henry, Y. Dai. Comptes Rendus Physique, 9 (2008) 389.

[3] Y. Dai, J. Henry, Z. Tong, X. Averty, J. Malaplate, B. Long. J. Nucl. Mater 415 (2011), 306.

[4] J. Henry, X. Averty, Y. Dai, J.P. Pizzanelli, J.J. Espinas. J. Nucl. Mater 386-388 (2009) 345.

[5] L. Hsiung, M. Fluss, S. Tumey, B. Choi, Y. Serruys, F. Willaime, A. Kimura. Phys. Rev. B 82 (2010) 184103. 
Irradiation resistance in a fusion environment: a challenge for structural materials.

J. Henry ${ }^{1}$, J-L. Boutard ${ }^{2}$

${ }^{1}$ CEA/DEN, SRMA, CEA Saclay

${ }^{2}$ Cabinet du Haut-Commissaire, CEA 


\section{MATERIALS FOR THE FIRST WALL: IRRADIATION} CONDITIONS

$\because$ MIN口S
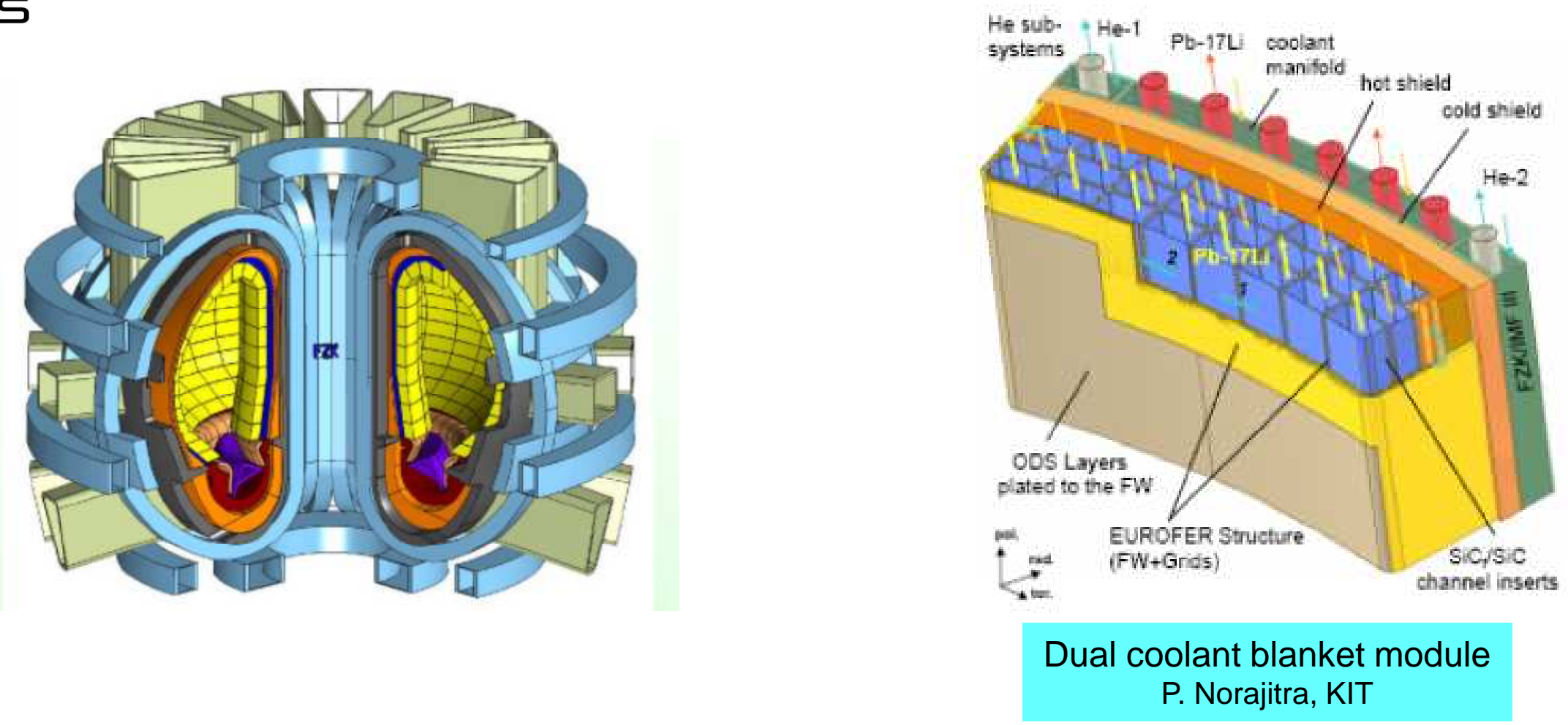

\begin{tabular}{|l|c|c|c|c|}
\hline & First Wall & Dose (dpa) & Temperature & appmHe/dpa \\
\hline ITER & Austenitic steel & $<3 \mathrm{dpa}$ & $<300{ }^{\circ} \mathrm{C}$ & $\sim 15$ \\
\hline DEMO & EUROFER & $50-80 \mathrm{dpa}$ & $300-550^{\circ} \mathrm{C}$ & $\sim 12$ \\
\hline Power Plant & ODS Ferritic Steels & $100-150 \mathrm{dpa}$ & $300-750^{\circ} \mathrm{C}$ & $\sim 12$ \\
\hline
\end{tabular}




\section{Cea OUTLINE}

\section{MINDS}

E Irradiation effects in candidate materials assessed using fission reactors. Is it relevant?

- 9Cr martensitic steels

- Main reasons for their selection (irradiation behaviour at $\mathrm{T}>400^{\circ} \mathrm{C}$ )

- Behaviour (tensile/impact) after high dose irradiation at $\mathrm{T}<400^{\circ} \mathrm{C}$ (fast reactor)

- Does Helium matter?

- ODS FM steels: promising candidates for fusion application?

- Conclusion 


\section{CeA ARE FISSION REACTORS RELEVANT TO STUDY IRRADIATION EFFECTS IN A FUSION ENVIRONMENT?}

\section{MIN口S}
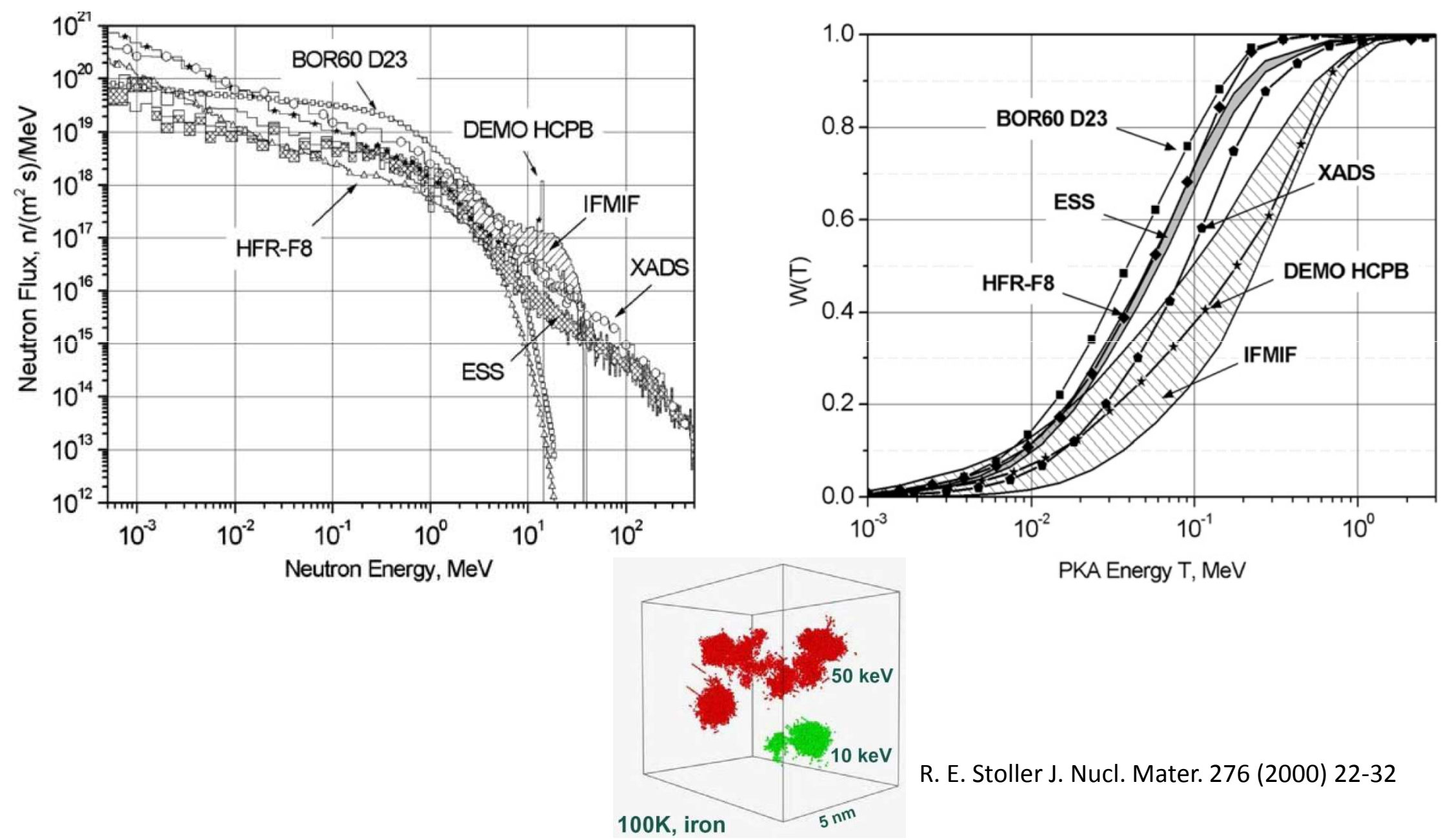

R. E. Stoller J. Nucl. Mater. 276 (2000) 22-32 


\section{Cea DAMAGE RECOVERY STAGES AFTER 14 MEV AND FISSION NEUTRON IRRADIATION AT 20K}

$\because \mathrm{MINDS}$
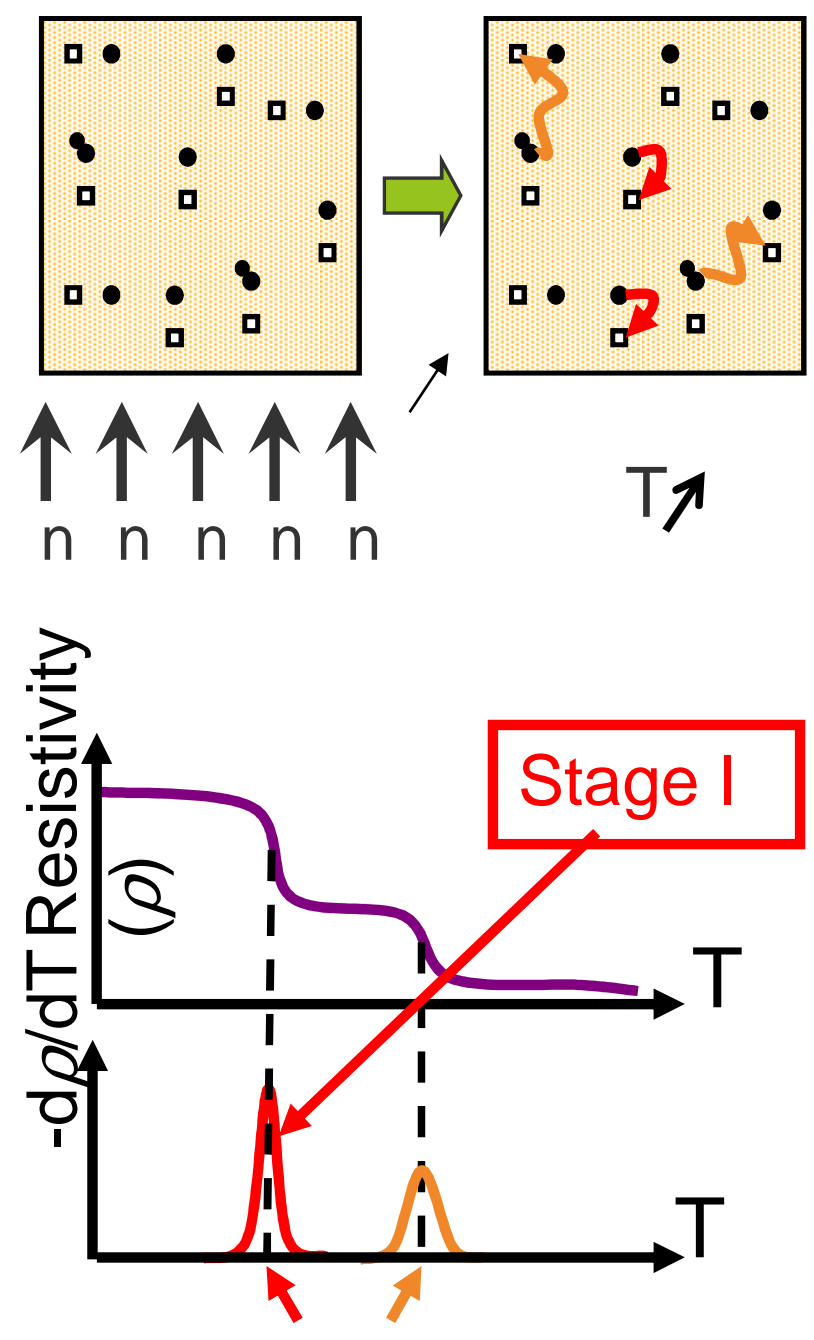

recovery stages

CEA-DEN

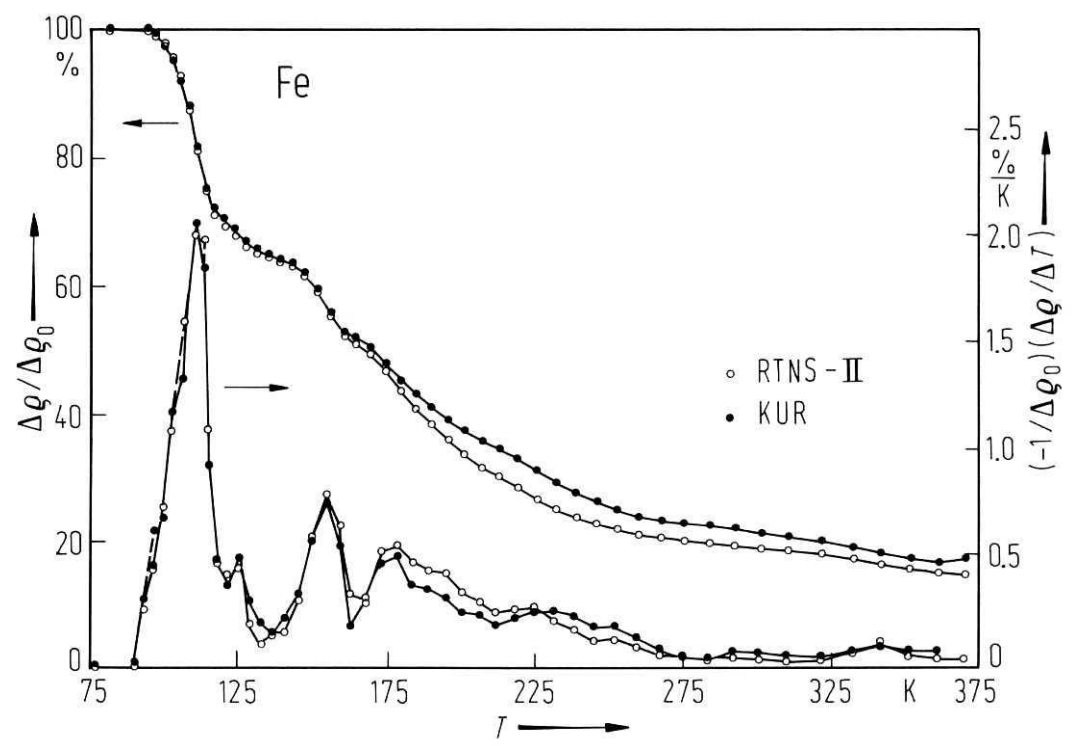

M. Matsui et al. J. Nucl. Mater. 155-157 (1988) 1284

\section{$14 \mathrm{MeV}$ and Fission Neutrons:} Same Surviving Defects 


\section{FM STEELS: IRRADIATION BEHAVIOUR AT T>400}

\section{MIN口S}

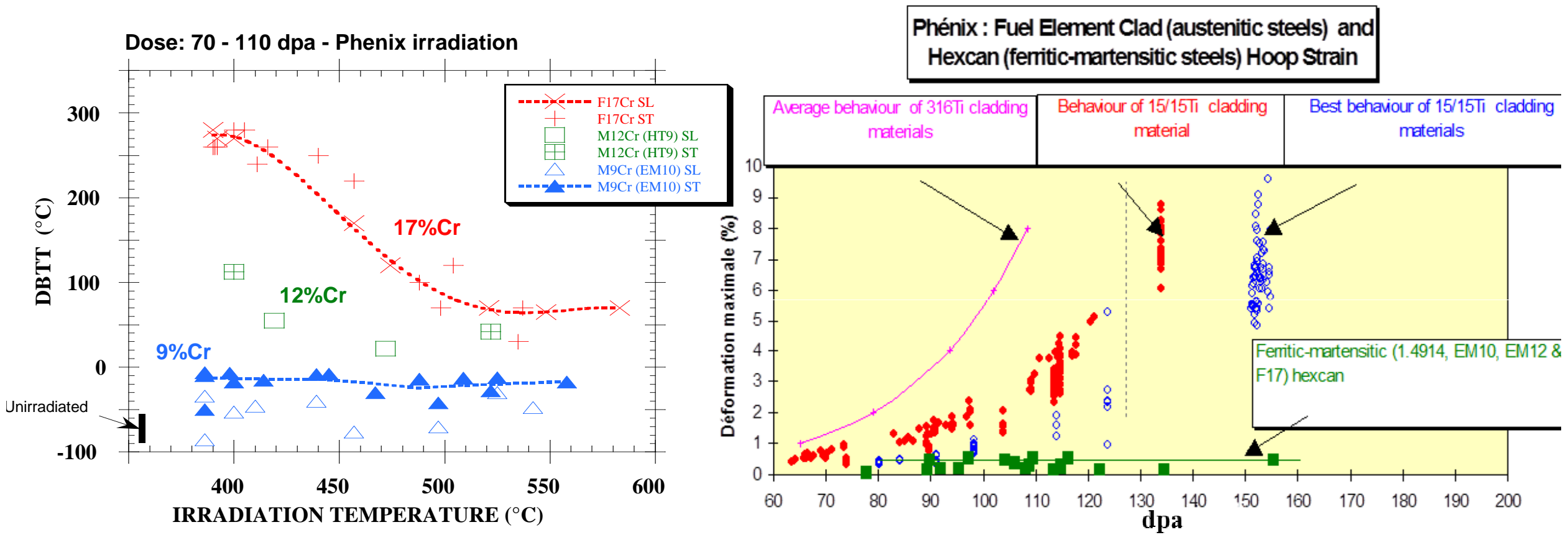

J.L. Séran et al. J. Nucl. Mater. 212-215 (1994) 588-593. 


\section{Cr TEMPERED MARTENSITIC STEELS: HARDENING AND TOTAL ELONGATION /DOSE (TIRR: $\left.325^{\circ} \mathrm{C}\right)$}

\section{MIN口S}

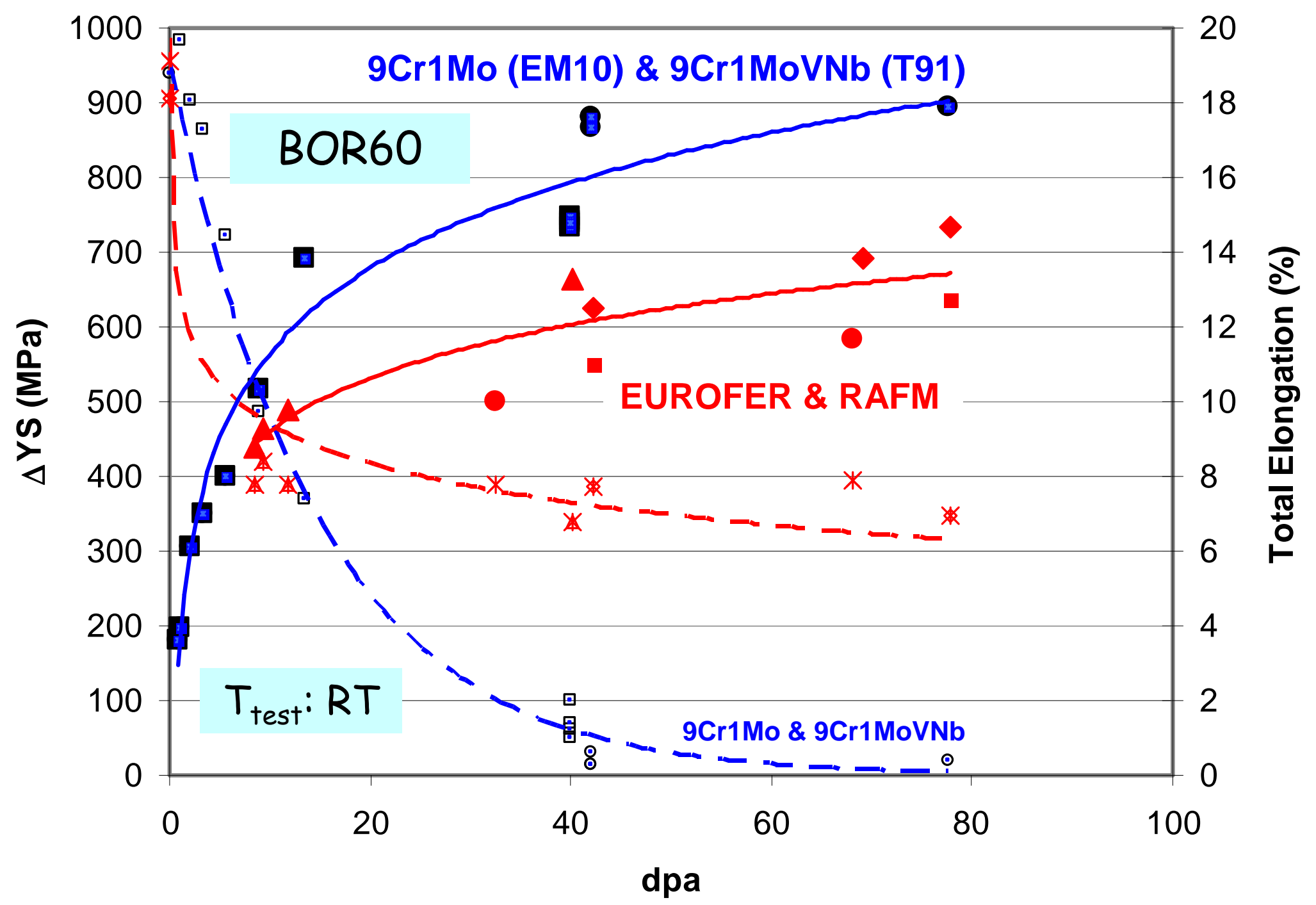


9Cr TEMPERED MARTENSITIC STEELS: IMPACT PROPERTIES ( $\left.T_{\text {IRR }}: 325^{\circ} \mathrm{C}\right)$

MIN口S

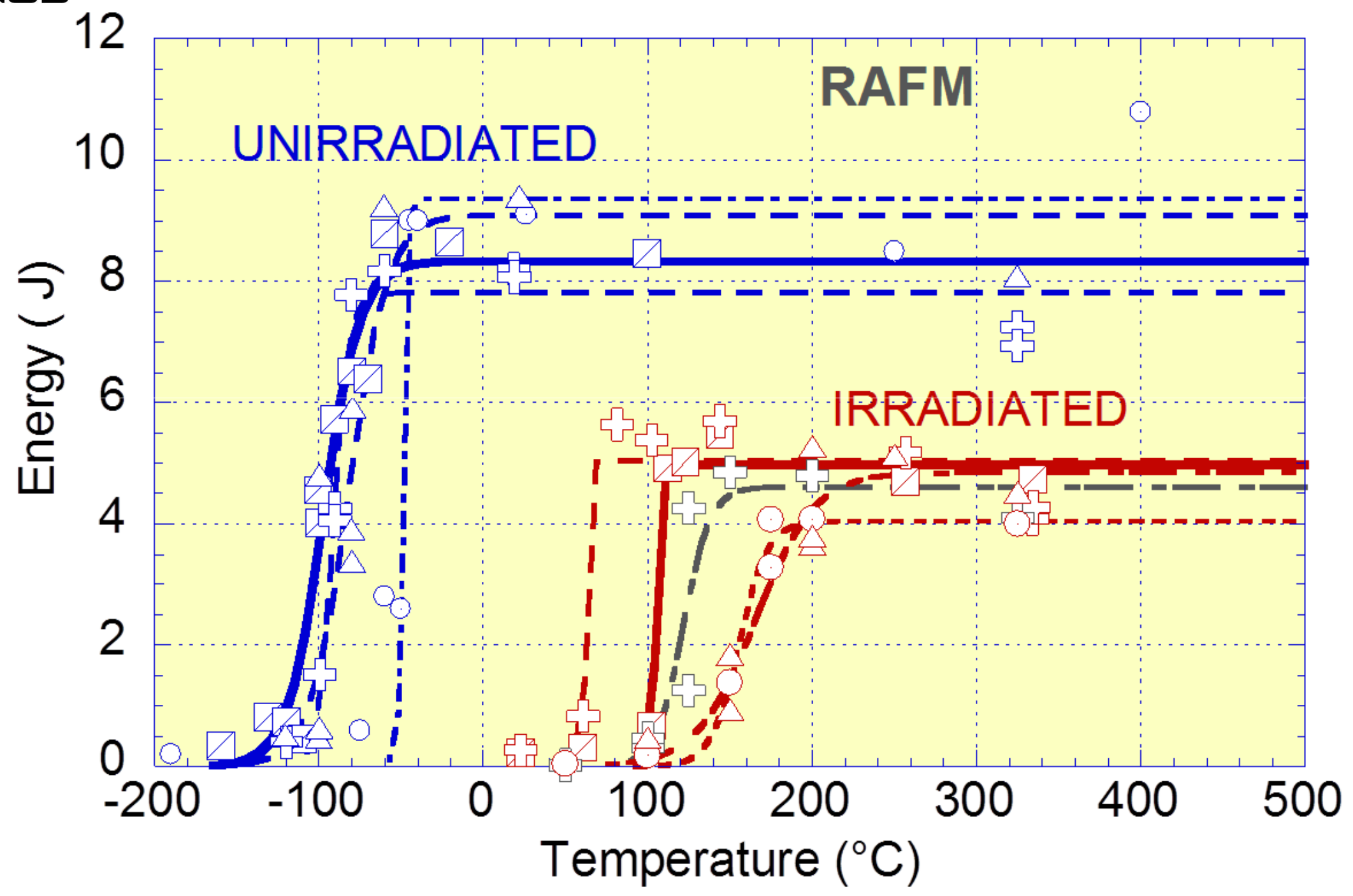




\section{Cea EUROFER IRRADIATED TO 78 DPA @ 325 MICROSTRUCTURE (TEM)}

\section{$\because$ MINDS}

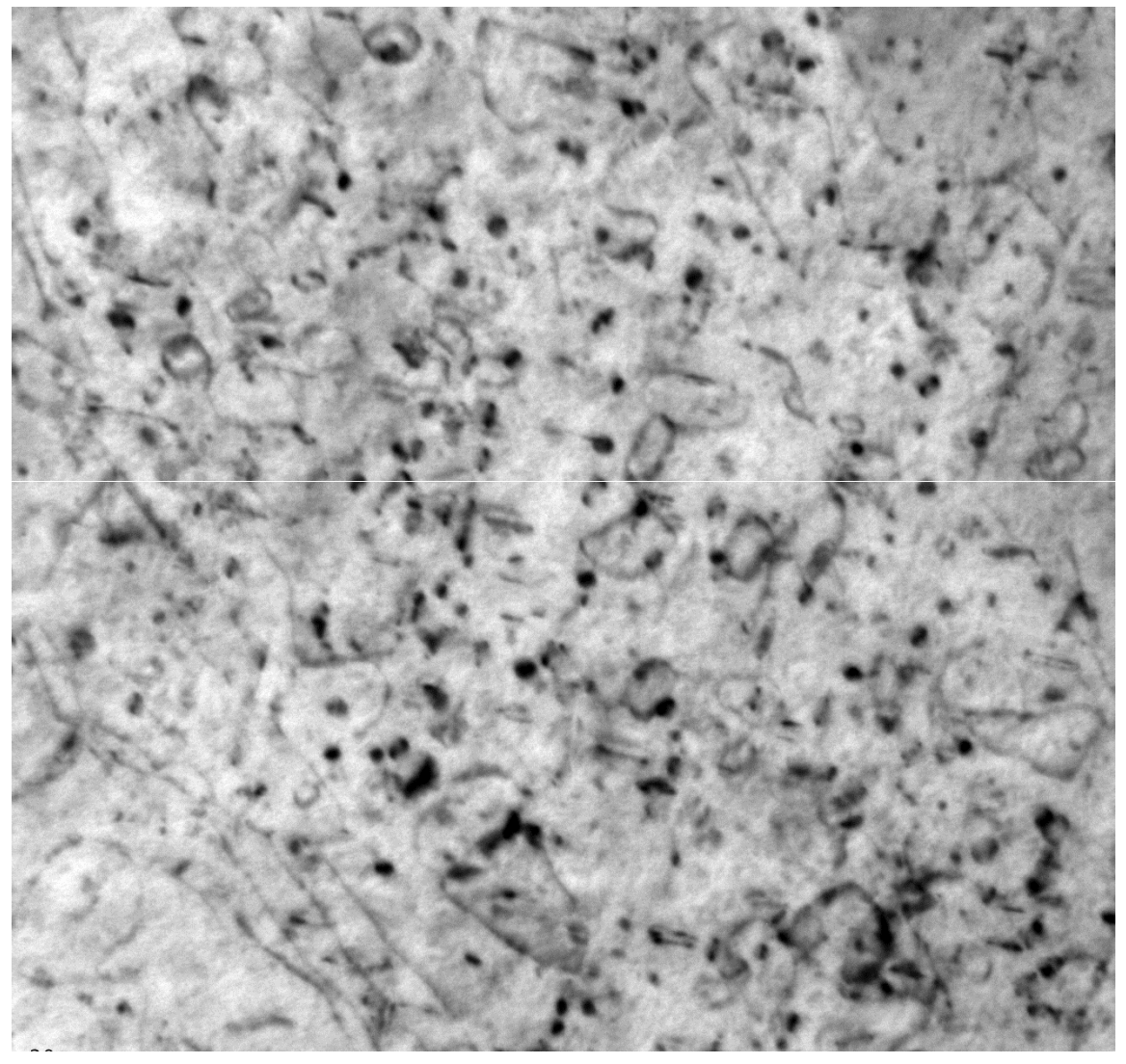

$b=a\langle 100\rangle$ and $a / 2\langle 111\rangle$ loops

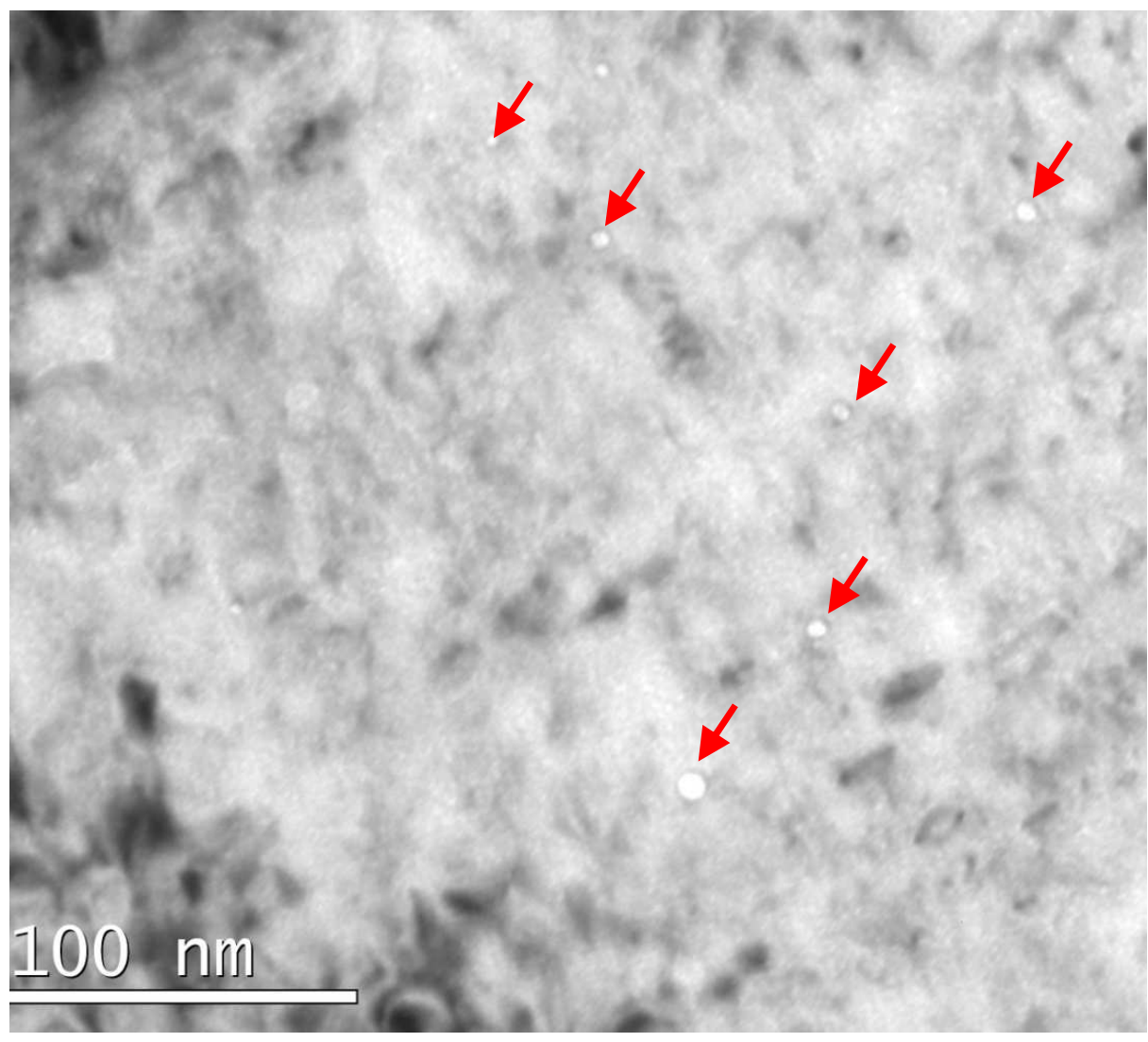

Voids 

MICROSTRUCTURE (SANS)

○MIN口S

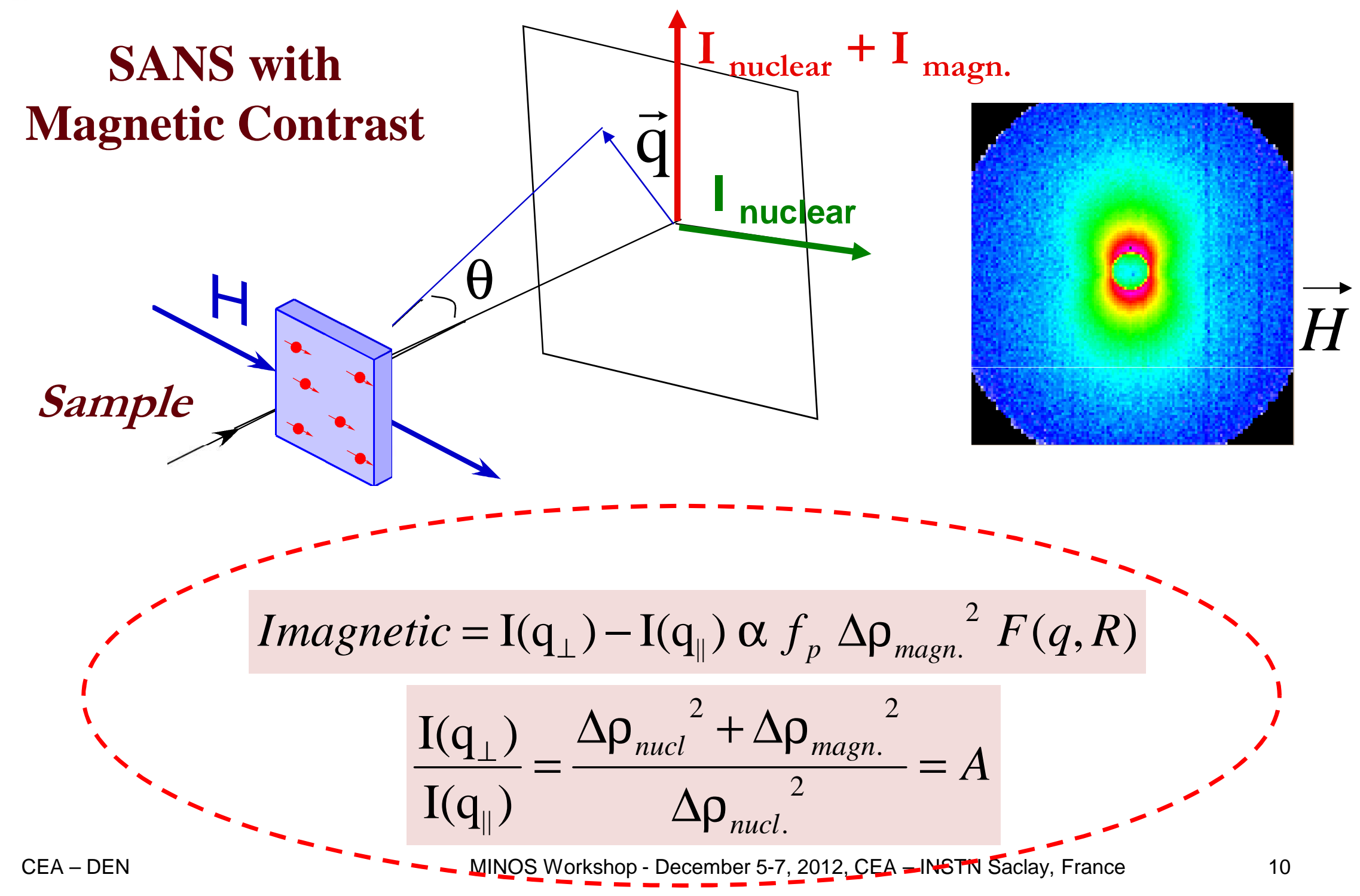




\section{EUROFER IRRADIATED TO 78 DPA @ 325ㄷ MICROSTRUCTURE (SANS)}

\section{MINDS}
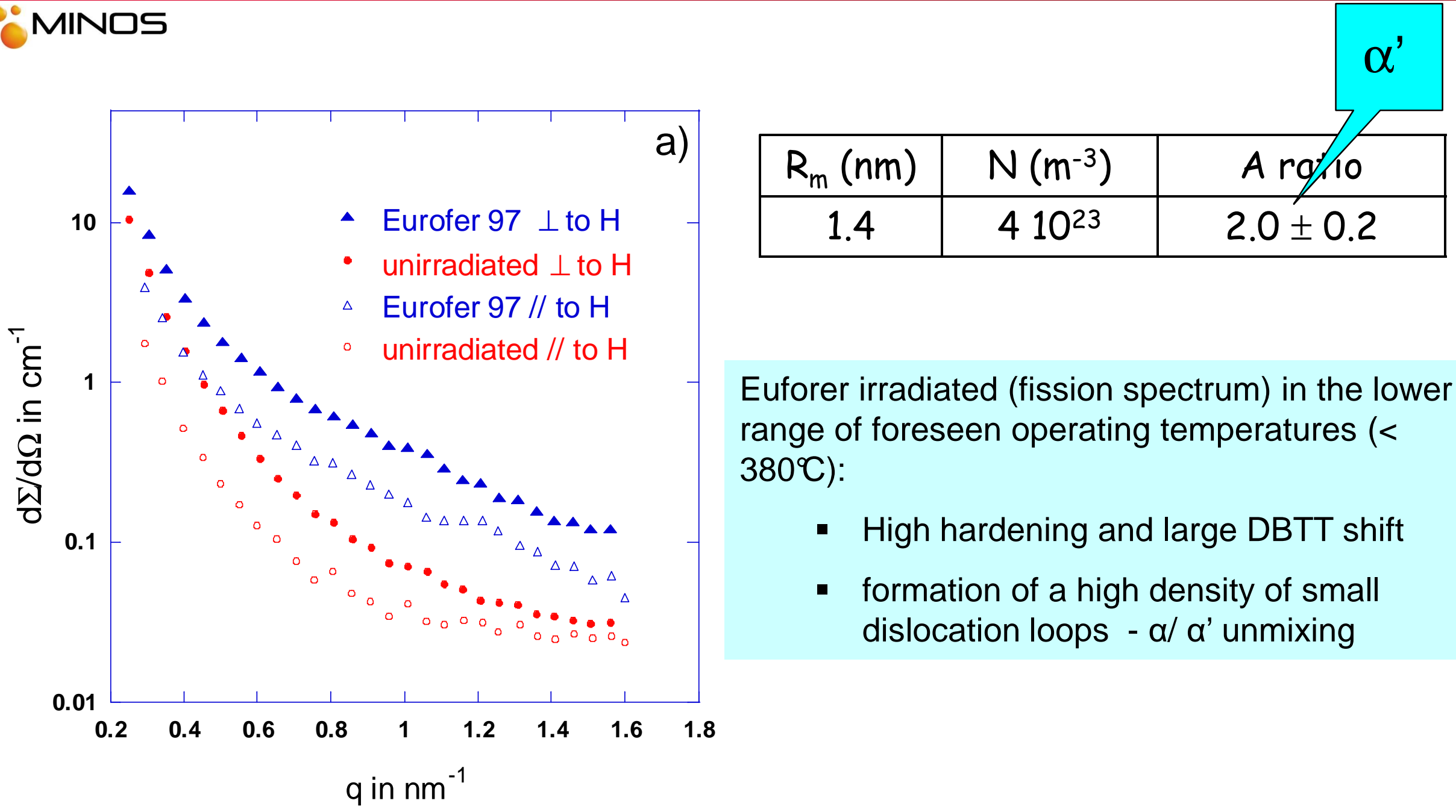

Euforer irradiated (fission spectrum) in the lower range of foreseen operating temperatures $(<$ $\left.380^{\circ} \mathrm{C}\right)$ :

- High hardening and large DBTT shift

- formation of a high density of small dislocation loops - $\alpha / \alpha^{\prime}$ unmixing 


\section{CQA DOES HELIUM MATTER?}

\section{MIN口S}

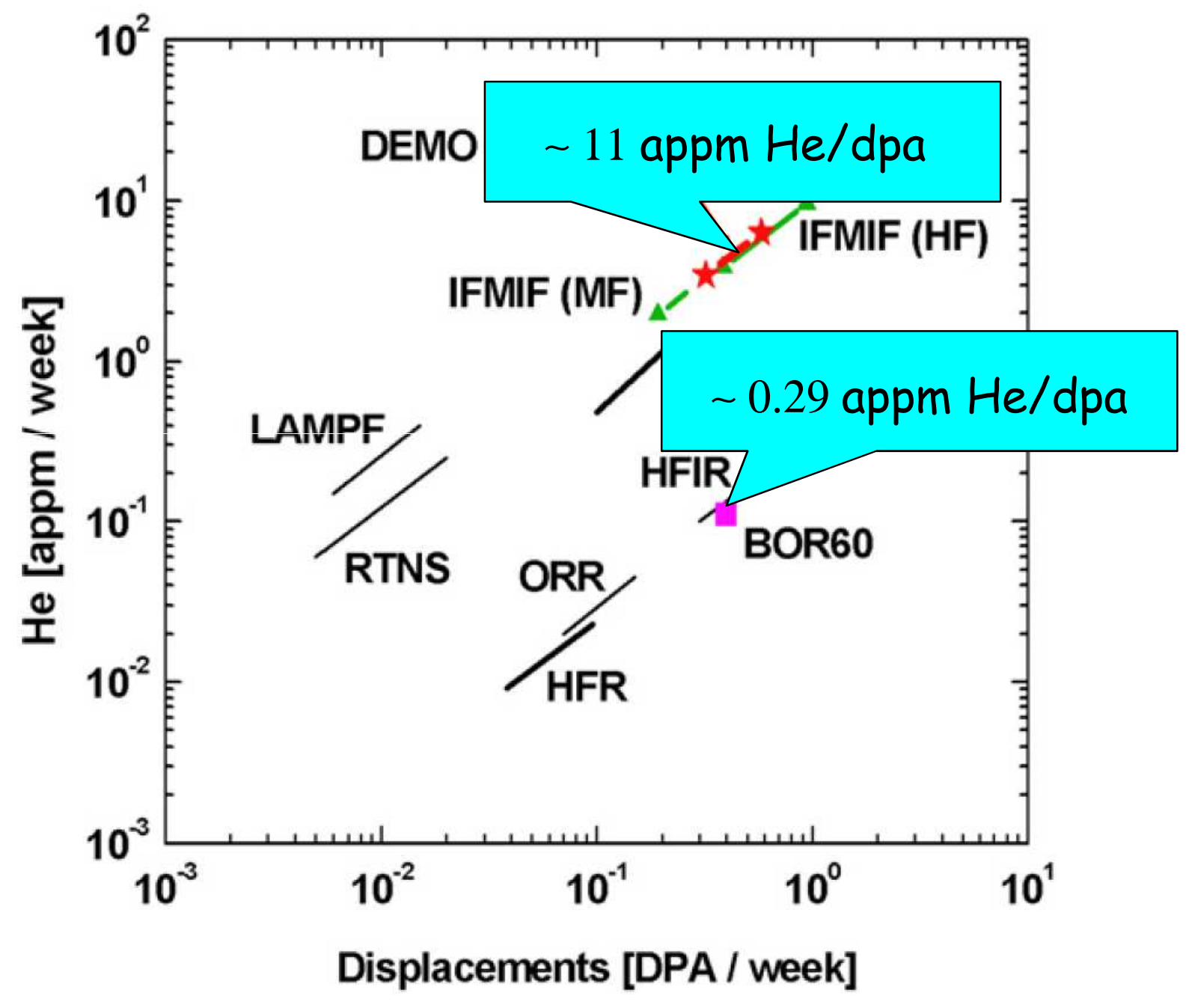



TO IMPLANTED HELIUM

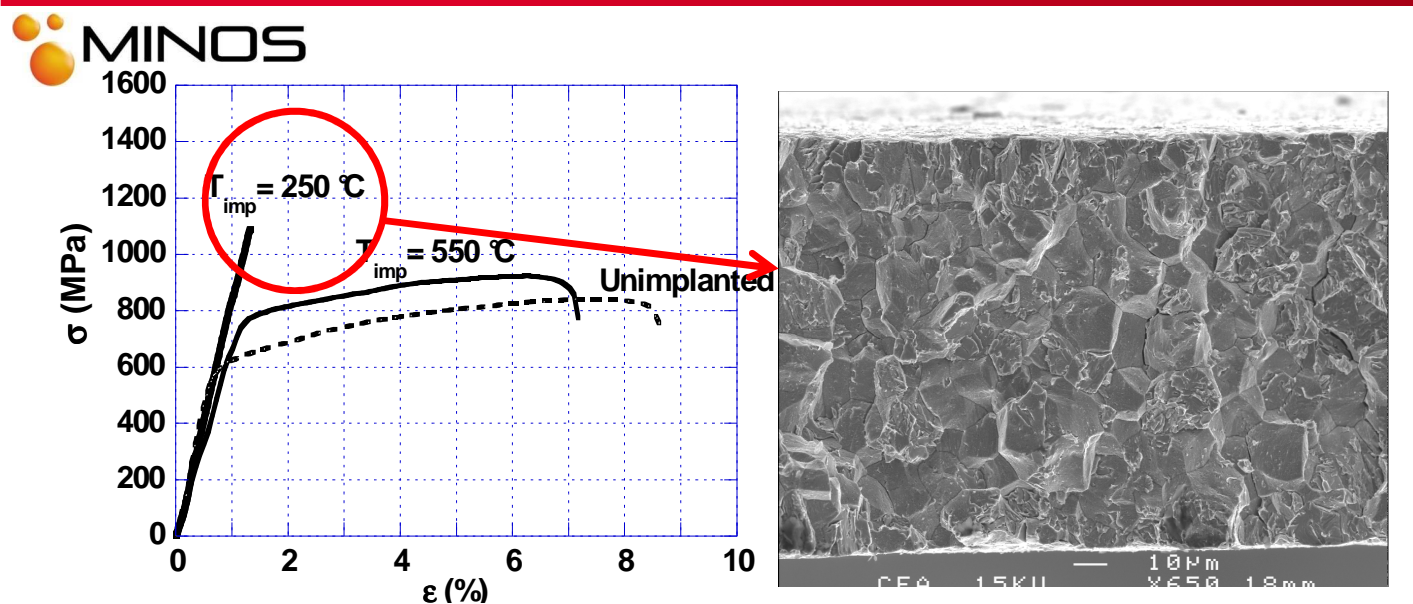

Tensile tests tests @ RT on samples implanted with $0,5 \%$ at $\mathrm{He} @ 250 \& 550^{\circ} \mathrm{C}$

CEA - DEN

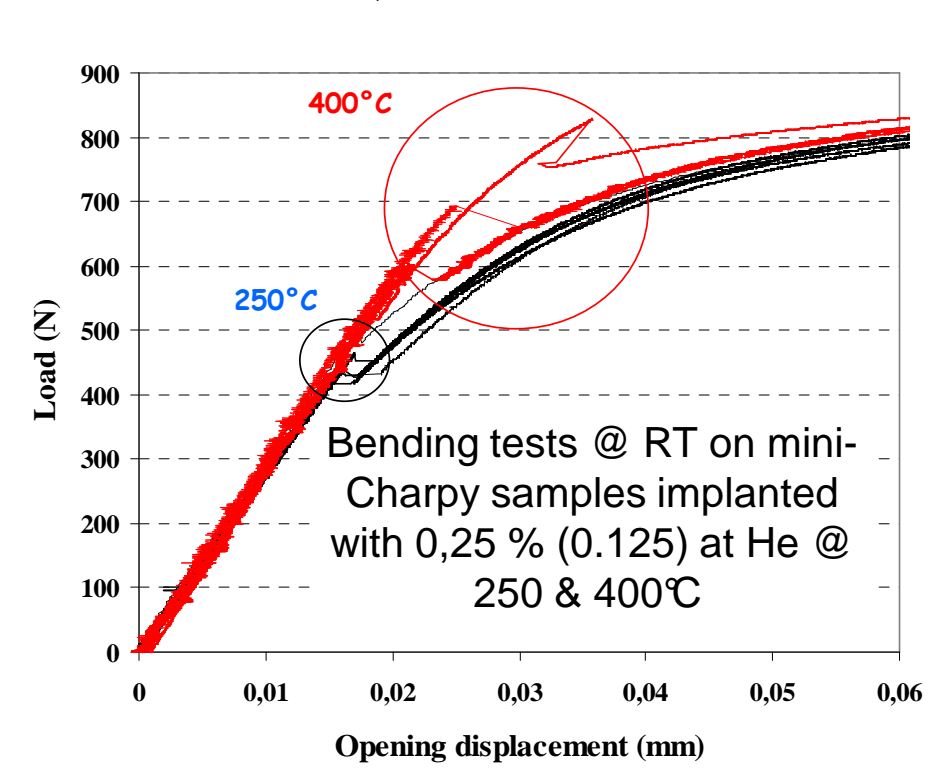

- Implanted He may induce (depending on concentration/implantation temperature) drastic embrittlement with occurrence of intergranular fracture mode

- Hardening (point defect clusters/He bubbles)

- Strong decrease of GB cohesion due to helium (C.C. Fu SRMP)
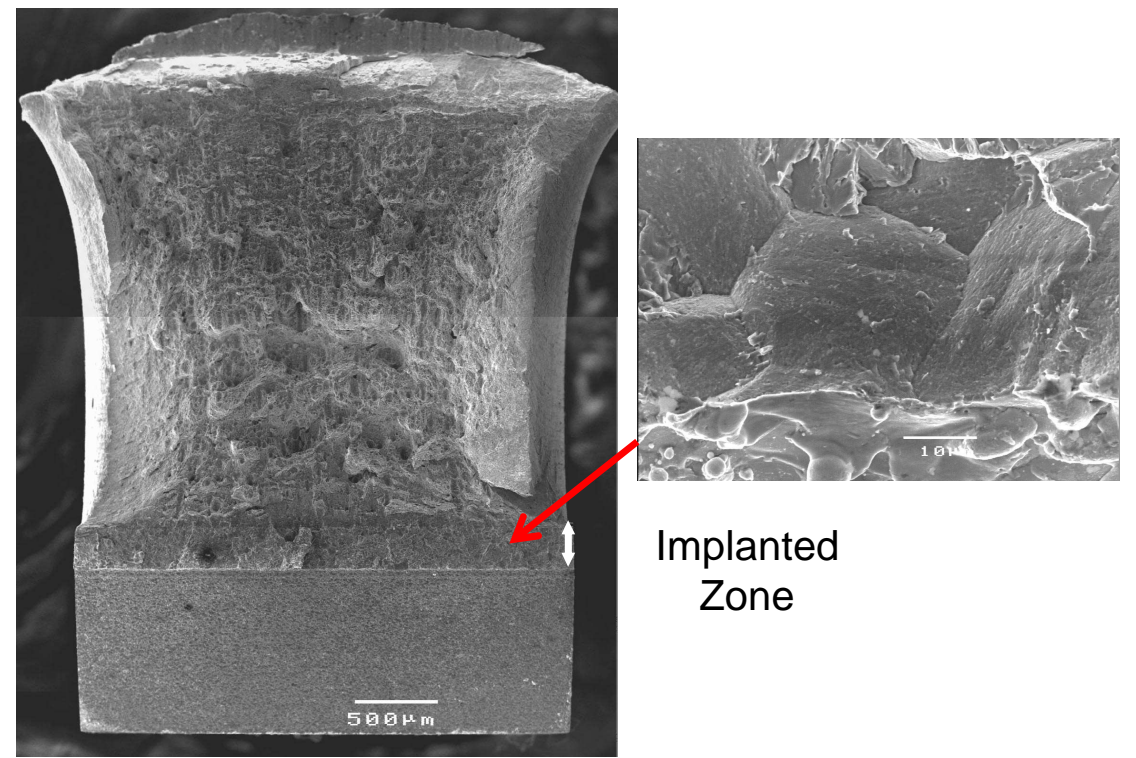

MINOS Workshop - December 5-7, 2012, CEA - INSTN Saclay, France 


\section{CeO 9CR-1MO (T91) FM STEEL: TENSILE PROPERTIES FOLLOWING IRRADIATION IN SPALLATION CONDITIONS}

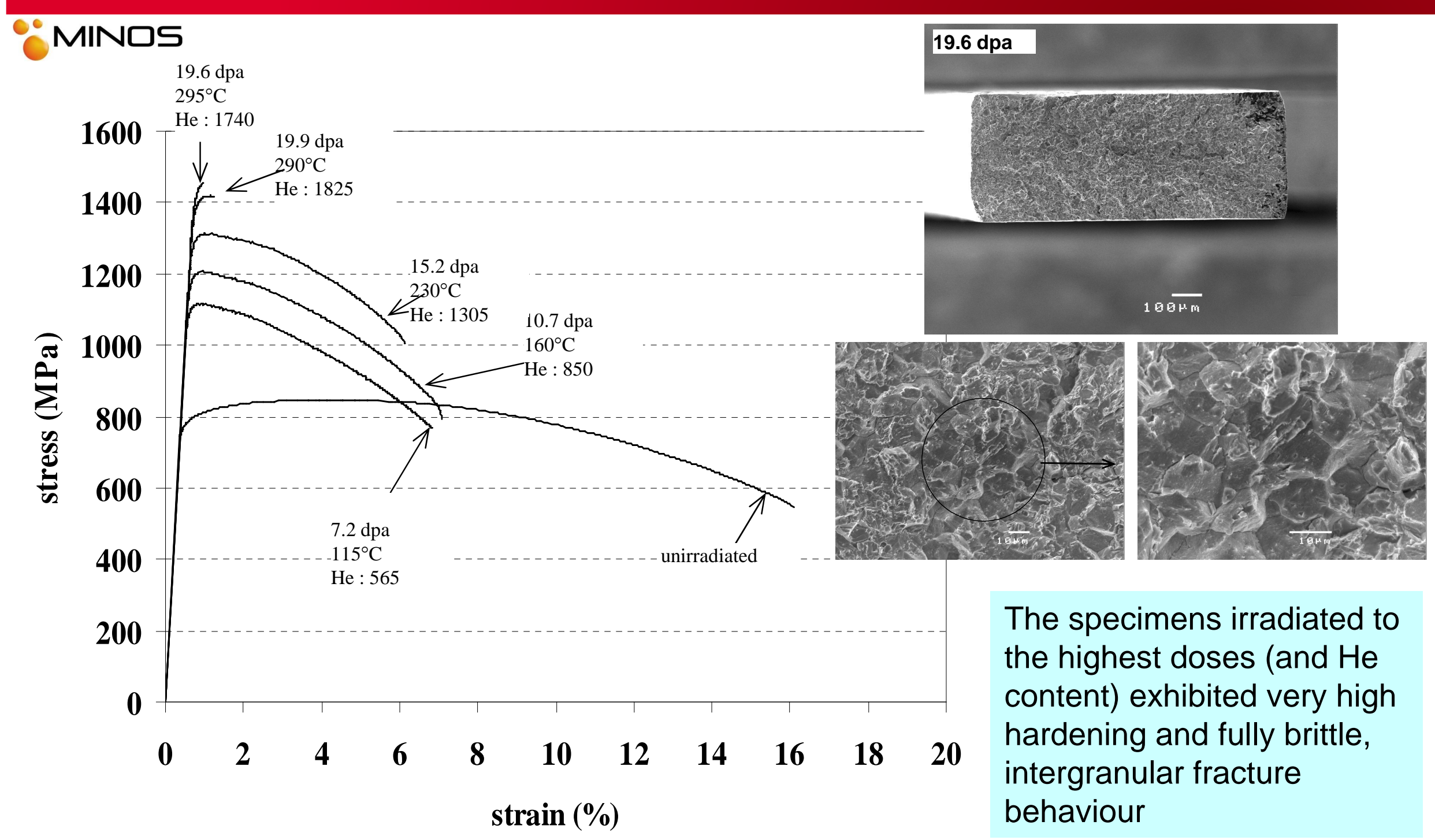




\section{cea}

\section{ODS FM STEELS: PROMISING MATERIALS FOR FUSION APPLICATION?}

\section{MIN口S}

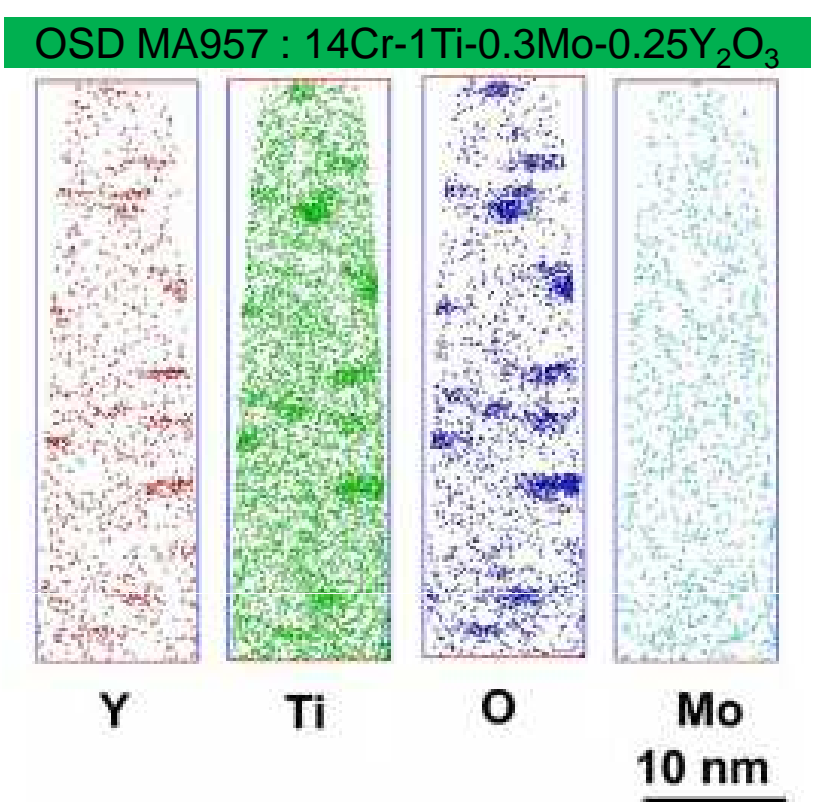

Miller et al., J. Nucl. Mater. 329-333 (2004) 338

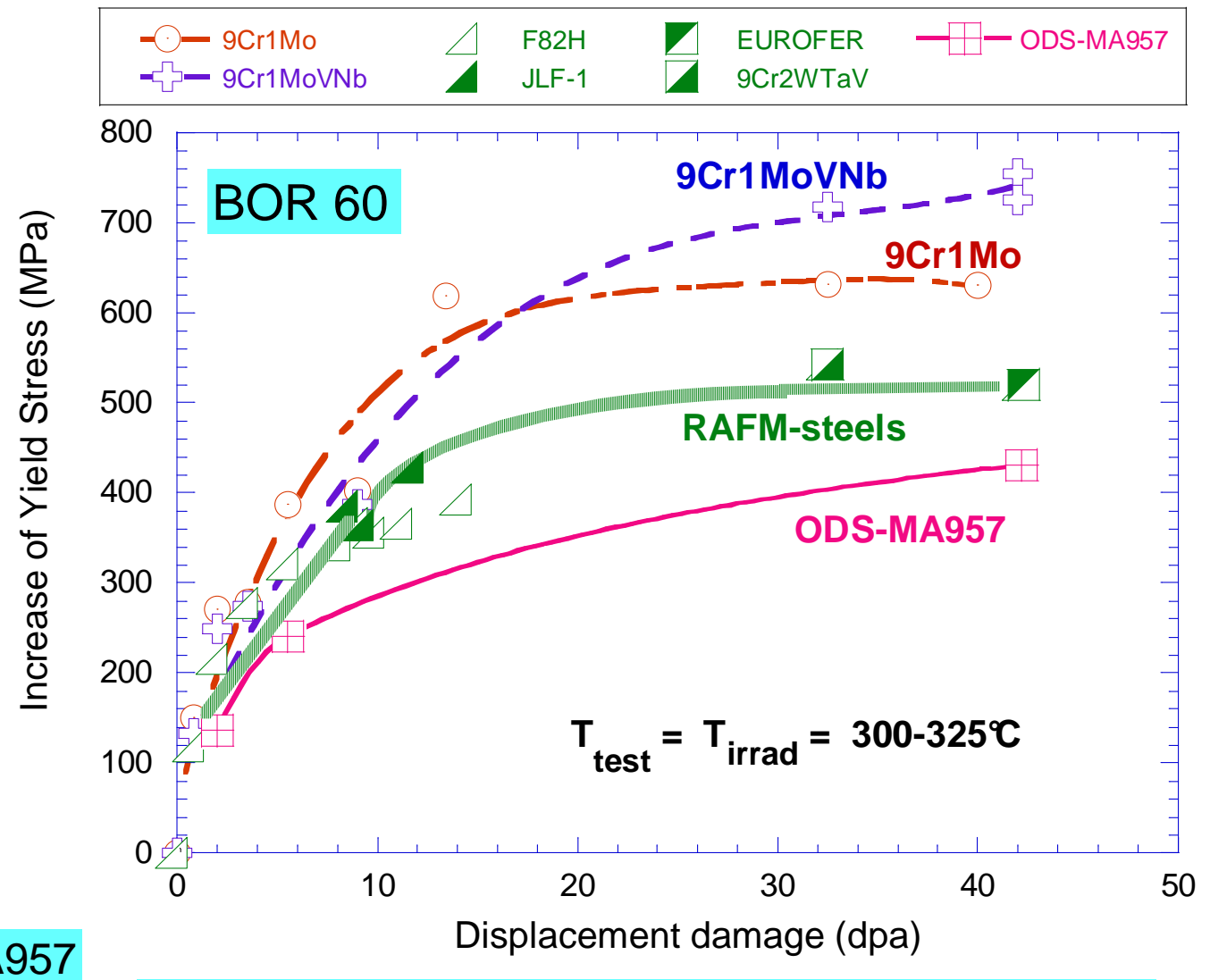

MA957 14\%Cr ODS: less hardening than F/M steels

contain high number densities of "nanoclusters" which could act as recombination sites for point defects/trapping sites for helium. 
MA957 ODS: TENSILE PROPERTIES FOLLOWING

\section{IRRADIATION IN SPALLATION CONDITIONS}

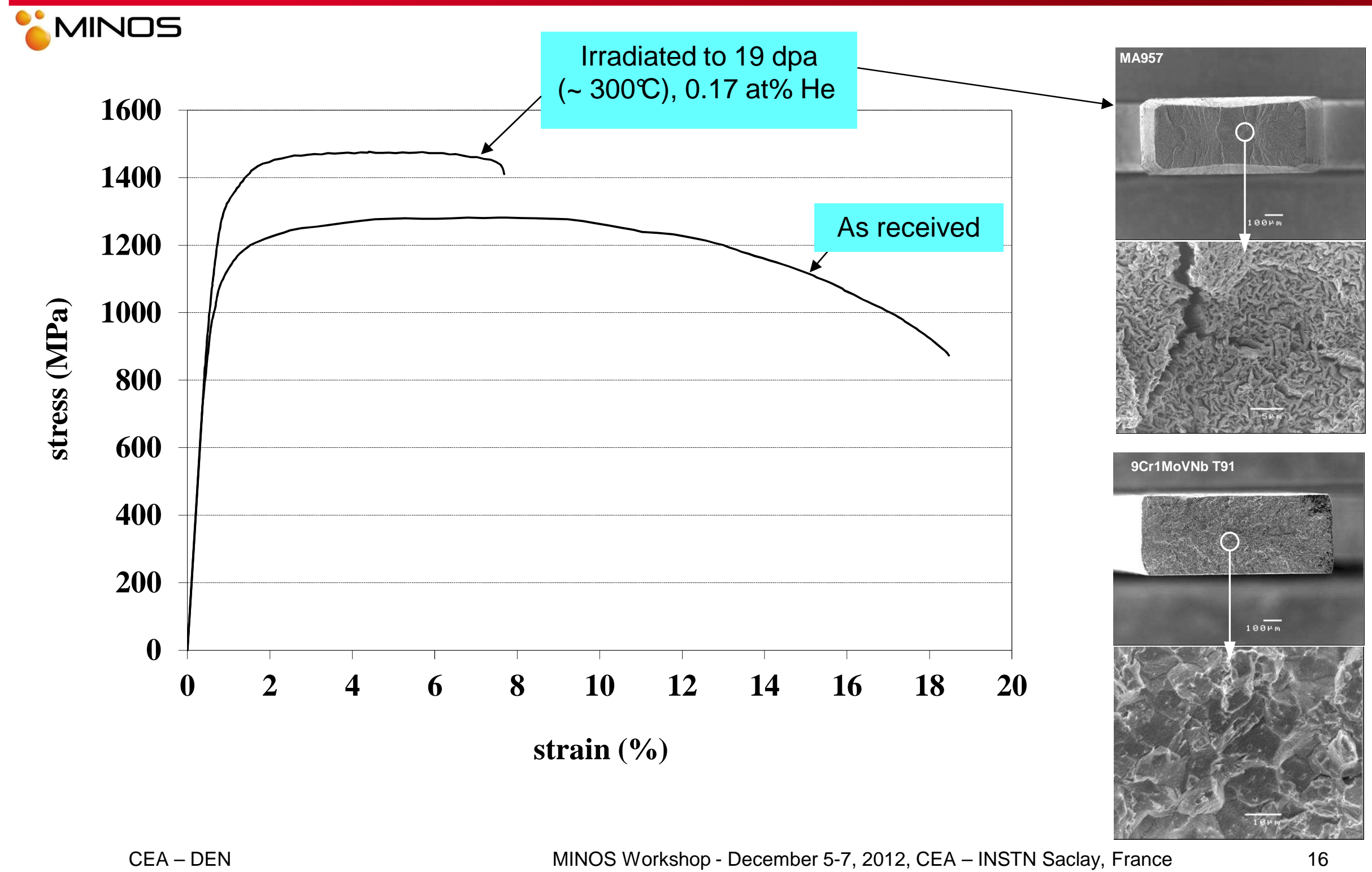


Ceح DUAL BEAM (JANNUS) - 425ㄷ, 40 DPA, 80 APPM HE/DPA K3-ODS 16CR-4.5 AL-0.3 Tl-2W-0.37 Y2O3

\section{$\because$ MINOS}
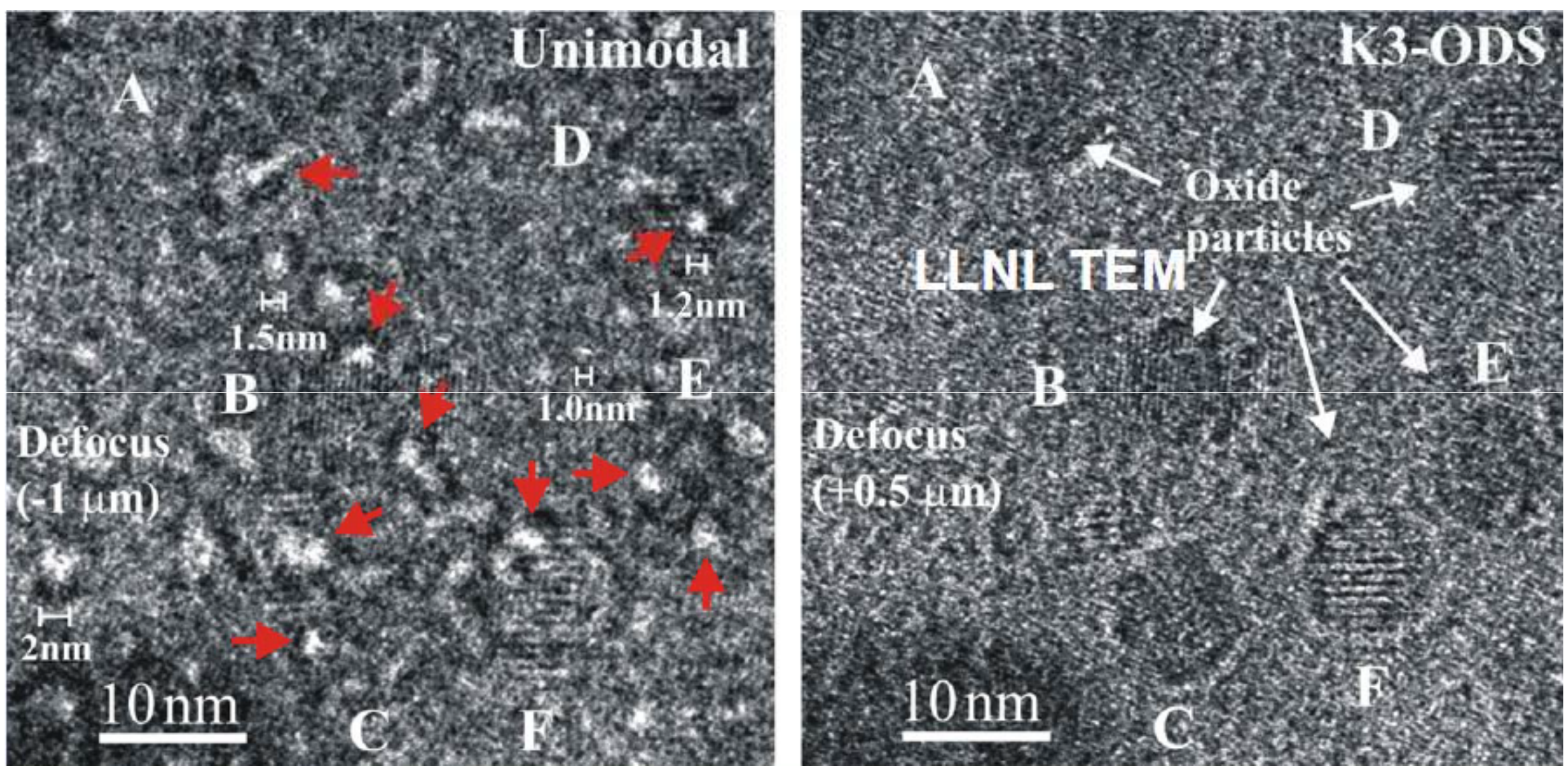

Hsiung et al., J. Nucl. Mater. 409 (2011) 72; M. Fluss et al, DIANA 1 Workshop, Aussois, April 2011 


\section{CONCLUSION: IRRADIATION BEHAVIOUR OF CANDIDATE MATERIALS FOR FUSION APPLICATION}

MIN口S

- 9Cr martensitic steels (Eurofer)

- were selected as candidate materials for fusion application due to their good radiation resistance (swelling/embrittlement) in a fission spectrum (at $\mathrm{T}>\sim 400^{\circ} \mathrm{C}$ )

- However they might not be suitable for operation at lower temperature due to:

- High radiation hardening and large DBTT shift when irradiated to high dose (80 dpa) at $325^{\circ} \mathrm{C}$ with fast neutrons (BOR60)

- Drastic embrittlement (brittle intergranular fracture mode) after irradiation in an environment with high He/dpa (spallation conditions)

- Low swelling retained in a fusion environment?

E Nanostructured ODS alloys: promising materials for fusion application?

- They displayed better radiation resistance in the lower irradiation temperature range compared to FM steels:

- Lower radiation hardening after 80 dpa irradiation in BOR60 at $325^{\circ} \mathrm{C}$

- Ductile behaviour (tensile tests) after irradiation in spallation conditions.

I Need of irradiation experiments in the relevant irradiation spectrum (intense $14 \mathrm{MeV}$ neutron source) 